\title{
The Search for Molecular Defects in Genetic Disease
}

\author{
H. Galjaard \\ Department of Clinical Genetics, Erasmus University, Rotterdam, The Netherlands
}

\section{INTRODUCTION}

In most wealthy industrialized countries, socioeconomic circumstances, hygiene and medical care have improved to such an extent that perinatal complications and congenital disorders have become the major causes of infant mortality and of chronic handicap in children [1].

In the past four decades, we have made impressive advances understandig the cytogenetic and molecular basis of congenital disorders. Dozens of syndromes associated with multiple physical handicaps and mental retardation have been related to specific numerical or structural chromosome aberrations. In situ hybridization and the development of a rapidly increasing number of DNA probes enable the detection of chromosomal abnormalities with a resolution down to the level of a single gene. The discovery of tumor-associated chromosomal aberrations, microdeletions, more than a hundred oncogenes, and the cloning of tumor suppressor genes are illustrations of the importance of molecular cytogenetics.

When I started my scientific career at the end of the fifties, some 1,000 syndromes were proven or suspected to be subject to Mendelian inheritance and this number has now increased to more than 6,600 [2]. Progress in elucidating the protein defects responsible for these single gene disorders has been much slower and currently about 400 protein defects have been delineated [3]. This knowledge has been important not only for basic research on biochemical pathways and cell biology, but has also provided new perspectives for early laboratory diagnosis of index patients, carrier detection, genetic counseling and in some instances, such as phenylketonuria, for newborn screening and early treatment [4]. In those instances where a protein defect is also expressed in cultured skin fibroblasts, amniotic cells or chorionic villi, prenatal diagnosis becomes possible for couples at increased risk $[5,6]$.

The discovery by Kan and Dozy [7] in 1978 that the gene mutation in sickle cell anemia could be detected at the DNA level by closely linked polymorphisms heralded a new era in basic research and in clinical genetics. During the past 15 years the genes involved 
in the most frequent Mendelian disorders have been identified, and gradually the 'oldfashioned' approach of searching for a responsible protein defect on the basis of pathological manifestations and chemical abnormalities has been replaced by that of "reverse genetics'. DNA technology offers fantastic new perspectives in basic research, and its clinical application for major multifactorial diseases in adulthood will form the basis of a new era of 'predictive medicine'.

Here I will summarize the search for molecular defects conducted by our department both at the level of proteins and genes, to illustrate some of the advances and changes in the research climate.

\section{SEARCH FOR PROTEIN DEFECTS}

Shortly after the first report of a genetic enzyme deficiency, methemoglobin reductase, Pauling was the first to relate a gene mutation to a defective primary structure of a protein in sickle cell anemia in 1949. Since then, several hundred genetic enzyme deficiencies and defective structural proteins have been described [3]. The majority of these protein defects are only expressed in specific cell types, tissues or body fluids and about a third are also demonstrable in erythrocytes, leukocytes or cultured skin fibroblasts. If the latter is the case, research on the exact nature of a protein defect is greatly facilitated, because cultured fibroblasts or transformed lymphocytes form a continuous source of mutant cell material, and the use of living cells also enables studies on the dynamics of biochemical processes under in vivo conditions.

For most Mendelian disorders, and especially for inborn errors of metabolism, attentive clinicians have found variations in clinical course and severity within 'the same' syndrome. It has, however, been very difficult to relate such clinical heterogeneity to differences in the nature of the responsible protein defect. This is partly because many diagnostic biochemical assays are performed under artificial conditions and the cell types studied in vitro may not be representative for the pathological manifestations as these develop in vivo.

Reading the history of a discovery of a particular protein defect and the subsequent studies on the relationship between its clinical and biochemical heterogeneity, it is aften striking how many years various research group have been working on one subject. Progress has sometimes been accelerated by the development of new analytical techniques, by the discovery of a patient with a rare clinical or biochemical variant and occasionally by serendipity. With a brief description of the discovery in our department of the protein defect responsible for three different lysosomal storage diseases, I would like to illustrate how difficult it sometimes is and also how lucky one can be obtaining a quick result. However, groups that have contributed to an understanding of the molecular pathogenesis of a disease at the protein level are always characterized by a rather long tradition in clinical chemistry and/or protein biochemistry and a focus on a relatively small and homogenous group of diseases. Examples of this can be found in reviews on various lysosomal storage diseases, the low-density-lipoprotein receptor work in familial hypercholesterolemia, certain organic acidurias and many other groups of diseases [3]. 


\section{The long road to the discovery of "the third protein "}

In 1968, Okada and O'Brien discovered that a deficiency of the lysosomal enzyme $\beta$-galactosidase is the underlying protein defect in patients with a rapidly progressive systemic disorder GM1 gangliosidosis [8]. Subsequently, patients with later-onset and milder clinical manifestation were described, who also showed B-galactosidase deficiency in all their cells. In 1974, the Dutch neurologist Loonen reported an unusual adult with skin lesions, who did not show the characteristics of a GM1 gangliosidosis but, nevertheless, had a $B$-galactosidase deficiency with some $10-15 \%$ residual activity. Somatic cell hybridization studies with cultured skin fibroblasts from patients with different clinical types of B-galactosidase deficiency showed that the protein defect in this unusual adult was based on a mutation in a gene other than that encoding $\beta$-galactosidase. Three years later, Wenger and collegues found $B$-galactosidase and neuraminidase deficiency coexisting in another patient and such a double lysosomal enzyme deficiency was subsequently also demonstrated in other patients who belonged to the same genetic complementation group [for a review see ref. 9].

The search for the protein defect that results in a combined $B$-galactosidase/neuraminidase deficiency took 4 years and several groups were involved. The ultimate discovery of 'the third protein' named protective protein [10], became possible thanks to the development of a radioimmunoprecipitation method that enabled lysosomal enzyme protein biosynthesis to be studied in cultured cells and thanks to the development of a specific inhibitor of the B-galactosidase active site. After another year, the relationship between deficiency in the newly discovered third protein and $\beta$-galactosidase deficiency became clear but it took a group of several researchers 6 years to establish the relationship with lysosomal neuraminidase [for a review see ref. 9].

The cloning of the gene encoding the protective protein also proved to be difficult and lasted about 4 years. Elucidation of the amino acid sequence of the protective protein, its homology with cathepsins in lower organisms [11] and a combination of molecular genetics and protein biochemistry finally led to complete insight into the molecular pathogenesis of this rare lysosomal disorder and the development of a relatively simple diagnostic test. A total of nearly 20 years and the efforts of several research groups and clinicians were required to reach this goal [Table 1].

\section{Table 1 - Elucidation of the molecular defect in B-galactosidase-deficient patients}

1968 Demonstration of $\beta$-galactosidase deficiency in $\mathrm{G}_{\mathrm{m}}$ gangliosidosis patients.

1975 Demonstration of two different gene mutations in different clinical variants.

1978 Description of a patient with coexistent B-galactosidase and neuraminidase deficiencies from both complementation group.

1982 Discovery of a new protein ('protective protein') and hereditary defect in B-galneur galactosialidosis patients.

1988 Cloning of gene on chromosome 20 encoding protective protein.

1989 Cloning of gene encoding B-galactosidase.

1993 Availability of diagnostic test for galactosialidosis, identification of gene mutations, large-scale production of the human protein ( $3 \mathrm{~d}$ structure, replacement therapy) and transgenic aniaml models. 


\section{Discovery of a new lysosomal disorder}

In complete contrast is the example of the discovery of a new lysosomal disease by a very small group in our department, normally involved in the (prenatal) diagnosis of patients with a genetic metabolic disease. In 1985, a German pediatrician Schindler saw two young brothers with severe psychomotor retardation. Chemical analysis of their urine showed an abnormal oligosaccharide pattern but despite pathological suggestions of a lysosomal storage disease, no deficiency of any of the lysosomal enzymes tested could be found [for a review see ref. 12]. When the patients' cultured fibroblasts were referred to us, van Diggelen, head of our diagnostic biochemical laboratory, tested the cells for several enzymes including $\alpha-\mathrm{N}$-acetylgalactosaminidase, simply because no clinical syndrome associated with a deficiency for this enzyme had yet been found. To everybody's surprise, the cells of both index patients were profoundly deficient in this enzyme [13], previously known as $\alpha$-galactosidase B, an enzyme closely resembling $\alpha$ galactosidase A, which is deficient in patients with X-linked Fabry disease [12].

Here, a new lysosomal storage disorder was found in a few days. The gene coding for $\alpha-N$-acetylgalactosaminidase had already been cloned by Desnick's group in Mount Sinai, New York, and hence mutation analysis at the DNA level could also be performed very quickly. DNA studies made clear that the genes encoding $\alpha-\mathrm{N}$-galactosaminidase and $\alpha$-galactosidase have evolved from the same ancestral gene. In the meantime, other clinical variants of the same disease have been reported [for review see ref./12].

\section{A new group of transport disorders}

In 1979, in northern Finland, three mentally retarded brothers and a female cousin were found to have neurologic symptoms and dysmorphic features. The only chemical abnormality was a marked urinary excretion of $\mathrm{N}$-acetylneuraminic acid $[14,15]$. Later, several dozen similar patients were found in the same region, after which the condition was named Salla disease. Among other ethnic groups, a more severe clinical variant of sialic acid storage disease (SASD) was described [for a review see ref. 16]. None of the enzymes involved in neuraminic acid metabolism showed any abnormality.

A small group in our cell biology and genetics department decided to search for the protein defect responsible for SASD, following the observation of an Italian patient with the severe clinical form of the disease. To facilitate in vitro studies of sialiac acid transport, a radiolabeled methylester of sialic acid was prepared and a lysosome isolation and enrichment procedure was developed. Studies of cultured fibroblasts from patients with Salla disease and the infantile form of SASD were found to accumulate sialic acid within the lysosome, suggesting that the egress of sialic acid out of the lysosome was defective. In a series of elegant experiments over 2-3 years, Mancini, Verheijen and their coworkers demonstrated that a defect in a proton-driven carrier protein in the lysosomal membrane is responsible for SASD [17]. This carrier was not only involved in the active transport of sialic acid but also of other acidic monosaccharides. Collaboration with the Finnish clinical geneticist Aula subsequently showed that patients with SASD also accumulate glucuronic acid in their lysosomes [18].

This work formed the basis for elucidating the molecular defect in patients with 


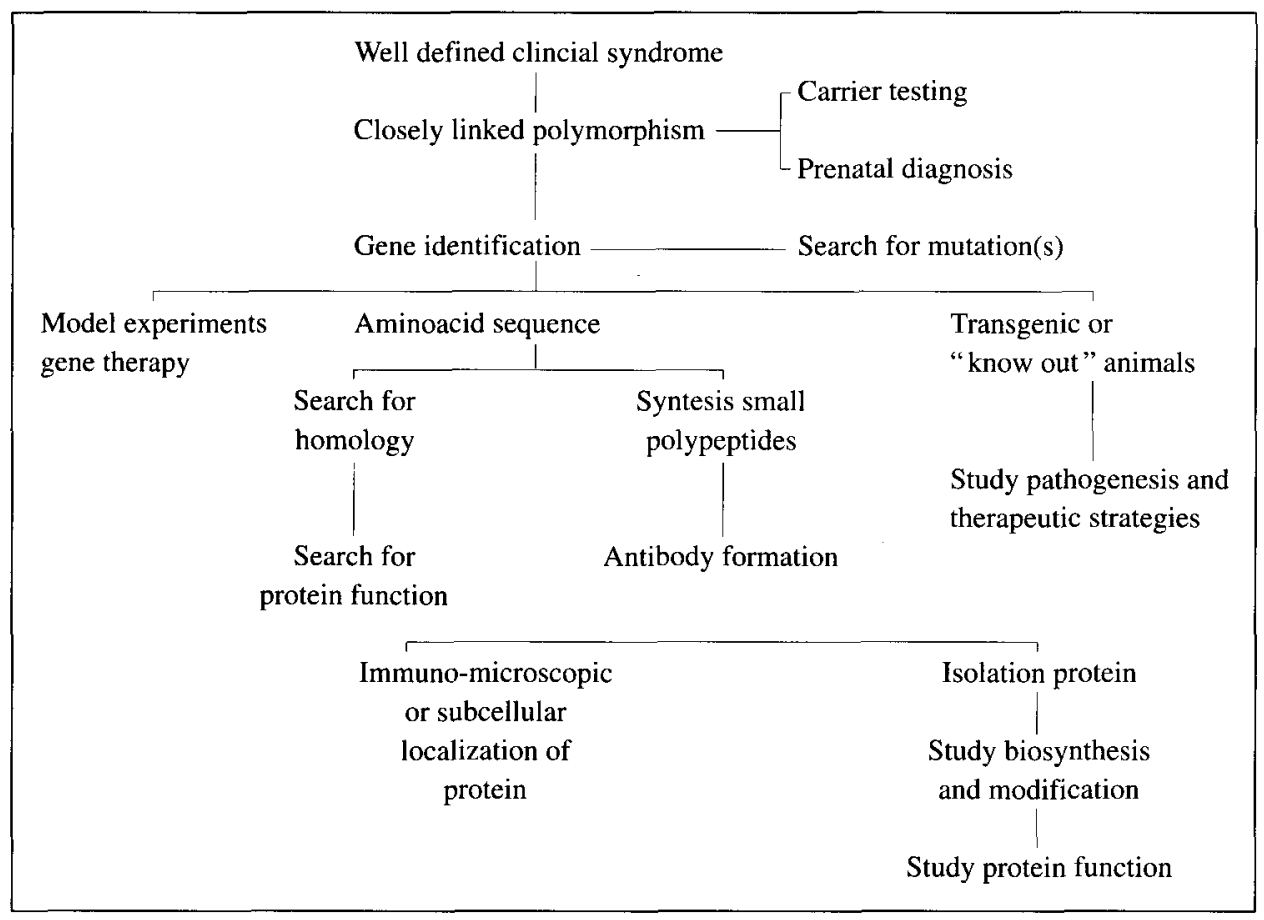

Fig. 1 - Research pathways in ' reversed genetics'.

SASD, and it also established the concept of new groups of lysosomal membrane transport disorders since, as a 'by-product', a protein carrier for glucose and other neutral sugars was found in the lysosomal membrane. It is likely that, in the future, patients with symptoms of unexplained lysosomal storage disorders might be found to have a genetic defect in one of the several transport proteins involved in the egress of low-molecularweight compounds derived from lysosomal degradation processes. An in vitro system of proteoliposomes has been developed to facilitate the isolation and identification of the various transport proteins [19].

This work is an example of collaborative work between attentive clinicians and biochemists, which, within a period of 5-7 years after the diagnosis of the first patients, led to the exploration of a new group of lysosomal membrane transport disorders.

\section{SEARCH FOR GENE DEFECTS}

The use of a closely linked polymorphism to demonstrate the gene mutation in sickle cell anemia [7] marked the beginning of a new era in the search for molecular defects in genetic disease. Investigation of closely linked polymorphisms revived extended family studies in cases of monogenic disorders of unknown molecular etiology. The finding of such a linkage in Huntington chorea in 1983, for the first time enabled early (prenatal) 
laboratory diagnosis without knowledge of the responsible protein defect [20]. It took 10 years for the gene defect to be identified [21].

Fortunately, in many other genetic diseases, the discovery of DNA linkage was followed more rapidly by the identification of the gene involved. The technique of positional cloning has been especially useful [22]. Among the 3,000 human genes that had been mapped by 1994, about 975 are involved in human disease [2]. Of these, about 150 enable the (prenatal) laboratory diagnosis of diseases with an as yet unknown protein defect. The advantage of gene analysis is, of course, that every cell type or tissue can be used for diagnosis and carrier testing and that prenatal diagnosis is always possible as soon as a gene mutation can be demonstrated.

The scheme depicted in Figure 1 illustrates the various options once a closely linked polymorphism and the responsible gene mutation(s) have been identified. In the case of diseases of unknown biochemical etiology, the amino acid sequence of the unknown protein can be derived from the DNA sequence. Peptides from various regions of the putative protein can be synthesized and antibodies against these can be raised. Using these antibodies, the unknown protein can be isolated and its subcellular localization can be studied in normal and mutant cells. After isolation, microsequencing of the amino acid sequence and comparison with the original DNA sequence of the disease gene will reveal whether the right protein has been localized and isolated.

The difficult part in reversed genetics is elucidating the function of an unknown protein. In some instances, the existence of a strong homology with proteins of known function in lower organisms is helpful, but at present we are only just beginning to understand the molecular pathogenesis of genetic diseases in cases where gene identification has been the starting point. A very promising experimental approach towards understanding better the pathogenesis of a human disease is the study of transgenic animals and of animals where a specific gene has been 'knockedout'. More and more animal models of human genetic diseases have become available andy may also serve to test new therapeutic strategies [for a review see ref. 23].

In contrast to the search for a protein defect, which has often required several research teams many years, the advances associated with gene analysis seem to proceed much faster. Some examples from our own department follow. In 1991, a research group led by the molecular biologist Oostra in Rotterdam, in collaboration with group from Atlanta Warren's and Nelson's in Houston, identified the (FMR) gene involved in the socalled fragile X syndrome [24]. This is a very common hereditary form of mental retardation, occuring in 1 of 1,200 males, whereas 1 in 600 females is a carrier of whom about one third are also (mildly) retarded.

The mutation in fragile $\mathrm{X}$ patients was found to be of a previosly unknown type, i.e. expansion of trinucleotide repeats above a critical minimum. The FMR gene in normal individuals was shown to have a variable number of CGG (coding arginine) repeats-up to 50 - whereas mentally retarded patients always showed more than 200 repeats. Female carriers have an intermediate number. Studies of different generations of an affected family revealed a new mechanism of mutation inheritance. From one generation to the next, the number of CGG repeats in the FMR gene may grow, and when the critical number of 200 repeats is exceeded, methylation prevents transcription and no protein can be demonstrated in the patients' cells.

Within 2 years of this important discovery, the relevant protein was identified and its 
subcellular localization established [31]. One year later, a 'knockout' mouse model for the fragile $X$ syndrome was established, which not only showed some characteristic physical features but also impaired performance in certain psychofunctional tests [26].

In the same 5-year period, the DNA research group and the DNA diagnostics group led by Halley in our department were able to identify one of the genes involved in tuberous sclerosis [27] and closely linked polymorphisms were found for the monogenic disorders multiple exostosis [28], hereditary paraganglioma [29] and for the developmental malformation, triphalangeal thumb [30]. The Huntington protein was also identified and localized for the first time [31]. Finally, a collaborative search for the tuberous sclerosis genes yielded as a by-product the discovery of the gene defect responsible for polycystic kidney disease (PKD) [32]. These two genes were identified following the attentive observation by the Portuguese cytogeneticist Santos of a very peculiar chromosome translocation family with balanced carriers and unbalanced traslocation patients with PKD and tuberous sclerosis.

This summary of our own activities searching for gene defects is meant to illustrate the very rapid rate of developments (Table 2). There are enormous challenges ahead of us thanks to the developments in DNA and protein research during the last few decades: (human) gene mapping, understanding the regulation of gene expression, elucidation of the cell biological processes underlying embryonic development and identification of the genetic factors involved in fetal malformations. The broad field of identifying genetic factors playing a role in multifactorial disorders, like cancers, cardiovascular diseases, diabetes and various psychiatric disorders has only just begun. It will be an enormous task to relate data about the interaction of several specific genes to data bases for environmental factors. Yet, the study of the interaction between genetic and environmental factors will provide clues to the etiology of most diseases in adulthood and will hopefully lead to new preventive and therapeutic strategies.

On the other hand, the rapid advances in gene identification are associated with great heterogeneity in research projects within one laboratory because neighboring genes usually have completely different functions and are involved in very different diseases (see Table 2).

Table 2 - Examples of progress in the search for gene defects in the department of Clinical Genetics, Erasmus University, Rotterdam, 1991-1994

Identification of fragile $\mathrm{X}$ syndrome gene [18].

Establishment of different types of mutation and inheritance (1991-1992).

Biosynthesis, subcellular localization of fragile $X$ protein [19].

Identificaiton and localization of Huntington protein [25].

Establishment of linkage for:

- hereditary paranglioma (chromosome 11q23) [23];

- multiple exostosis (chromosome 11 pericentric) [22];

- triphalangeal thumb (chromosome 7q33) [24].

Identification of tubersclerosis gene on chromosome 16p [21].

Collaborative work identifying the PKD gene on chromosome 16p [32].

Knockout mouse model for human fragile X syndrome [20] 
To make a real contribution to understanding molecular pathogenesis, a research group has to focus on a limited number of projects and build up expertise in specific cell biological processes or a particular group of disorders, as was the case in the period when protein defects were being sought.

Another problems for young researchers is the difficulty acquiring a scientific identity in a period of large consortia and at best being an author amidst twenty or thirty other people. International competition, commercialization and lack of openness also complicate the life of the contemporary molecular biologist. Finally, the low priority of research on the political agenda in most Western countries and the negative public attitude towards psychosocial and ethical aspects of new clinical applications of gene technology are not in line with the enormous opportunities summarized above.

However, these are the thoughts of an elderly head of department and, as in research, things will always work out contrary to expectations. I am sure that the next generation of clinicians and researchers will find novel approaches to deal with the problems and to create sufficient perspectives to meet the experimental, clinical and social challenges in future genetics [39].

\section{REFERENCES}

1. Galjaard H: Genetic technology in health care: A global view. Int J Tech Assess 1994; 10, 4: 527-545.

2. McKusick VA: Mendelian Inheritance in Man, ed. 7. Baltimore, Johns Hopkins University Press, 1994.

3. Scriver CR, Beaudet AL, Sly WS, Valle D (eds): The Metabolic and Molecular Bases of Inherited Disease, ed 7. New York, McGraw Hill, 1995.

4. Emery AEH, Rimoin DL (eds): Principles and Practice in Medical Genetics, ed 2. Edinburgh, Churchill Livingstone, 1991.

5. Drife JO, Donnai D (eds): Antenatal Diagnosis of Fetal Abnormalities. Berlin, Springer, 1991.

6. Milunsky A (ed): Genetic Disorders and the Fetus. Baltimore, Johns Hopkins University Press, 1992.

7. Kan YW, Dozy AM: Polymorphism of DNA sequence adjacent to human B globin structural gene: Relationship to sickle mutation. Proc Natl Acad Sci USA 1978; 75: 5631-5635.

8. Suzuki Y, Sakubara, H, Oshima A: B-Galactosidase deficiency: GM1-gangliosidosis and Morquio B disease; in Scriver CR, Beaudet Al, Sly Ws, Valle, D/ (eds): The Metabolic and Molecular Bases of Inherited Disease, ed. 7. New York, Mc Graw Hill, 1995, pp 2785-2824.

9. D'Azzo A, Andria G, Strisciuglio P, Galjaard H: Galactosialidosis; in Scriver CR, Beaudet AL, Sly, WS, Valle D, (eds): The Metabolic and Molecular Bases of Inherited Disease, ed 7. New York, McGraw Hill, 1995, pp 2825-2838.

10. D'Azzo A, Hoogeveen A, Reuser AJ, Robinson D, Galjaard H: Molecular defect in combined B-galactosidase and neuraminidase deficiency in man. Proc Natl Acad Sci USA 1982; 79: 4535-4539.

11. Galjart NJ, Morreau H, Willemsen R, Gillemans N, Bonten EJ, d'Azzo A: Human lysosomal protective protein has cathepsin-A-like activity distinct for its protective function. J Biol Chem 1991; 266: 14754-14762.

12. Desnick RJ, Wang AM; $\alpha$-N-Acetylgalactosaminidase deficiency: Schindler disease; in Scriver R, Beaudet AL, Sly, WS, Valle D, (eds): The Metabolic and Molecular Bases of Inherited Disease, ed 7. New York, McGraw Hill, 1995, pp 2509-2528. 
13. Van Diggelen OP, Schindler D, Kleijer WJ, Huijmans JMG, Galjaard H, Linden HU, PeterKatalinic J, Egge H, Dabrowski U, Cantz M: Lysosomal $\alpha-\mathrm{N}$-acetylgalactosaminidase deficiency: A new inherited metabolic disease. Lancet 1987; ii: 804-805.

14. Aula PP, Autio S, Raivio KO, Rapola J, Thoden CJ, Koskela SL, Yamashina L: 'Salla disease ': A new lysosomal storage disorder. Arch Neurol 1979; 36: 88-94.

15. Renlund M, Aula PP, Raivio KD, Autio S, Sainio K, Rapola J, Koskela SL: Salla disease: A new lysosomal storage disorder with distributed sialic acid metabolism. Neurology 1983; 33: 57-66.

16. Gahl WA, Schneider JA, Aula PP: Lysosomal transport disorders: Cystinosis and sialic acid storage disorders; in Scriver CR, Beaduet AL, Sly, WS, Valle D, (eds): The Metabolic and Molecular Bases of Inherited Disease, ed 7. New York, McGraw Hill, pp 3763-3798.

17. Mancini GMS, De Jonge HR, Galjaard H, Verheijen FW: Characterization of a proton-driven carrier for sialic acid in the lysosomal membrane: Evidence for a group specific transport system for acidic monosaccharides. J Biol Chem 1989; 264: 15247-15254.

18. Mancini GMS, Beerens CEMT, Aula PP, Verheijen FW: Sialic acid storage diseases. J Clin Invest, 1991; 87: 105-111.

19. Mancini GMS, Beerens CEMT, Galjaard H, Verheijen FW: Functional reconstitution of the lysosomal sialic acid carrier into proteoliposomes. Proc Natl Acad Sci USA, 1992; 89: 66096613.

20. Gusella JF, Wexler NS, Conneally PM, Naylor SL: A polymorphic DNA marker genetically linked to Huntington's disease. Nature 1983; 306: 234-238.

21. The Huntington Disease Collaborative Research Group: A novel gene containing a trinucleotide repeat that is expanded and unstable in Huntington disease chromosomes. Cell 1993; 72: $971-983$.

22. Colling FS: Positional cloning: Let's not call it reverse anymore. Nat Genet 1992; 1:3.

23. Beaudet AL, Scriver CR Sly WS, Valle D: Genetics, biochemistry and molecular basis of variant human phenotypes; in Scriver CR, Beaudet AL, Sly, WS, Valle D, (eds): The Metabolic and Molecular Bases of Inherited Disease, ed 7. New York, McGraw Hill, 1995, pp 53-228.

24. Verkerk AJMH, Pieretti M, Sutcliffe JS, Fu Y, Kuhl DP; Pizzuti A, Reiner O, Richards S, Victoria MF, Zhang FP, Eussen BE, Van Ommen GJB, Blonden LAJ, Riggens GJ, Chastain JL, Kunst CB, Galjaard H, Caskey CT, Nelson DL, Oostra BA, Warren ST: Identification of a gene (FMR-1) containing a CGG repeat coincident with a fragile $\mathrm{X}$ breakpoint cluster region exhibiting length variation in Fragile X syndrome. Cell 1991; 65: 905-914.

25. Verheij C, Bakker CE, de Graaff E, Keulemans J, Willemsen R, Verkerk AJMH, Galjaard H, Reuser AJJ, Hoogeveen AT, Oostra BA: Characterization and localization of the FMR-1 gene product associated with fragile X syndrome. Nature 1993; 363: 722-724.

26. The Dutch-Belgian Fragile X Consortium: FMR-1 knockout mice: A model to study Fragile $X$ mental retardation. Cell 1994;78: 23-33.

27. The European Chromosome 16 Tuberous Sclerosis Consortium: Identification and characterization of the tuberosis sclerosis gene on chromosome 16. Cell 1993; 75: 1305-1315.

28. Wu YQ, Heutink P, de Vries BA, Sandkuyl LA, van den Ouweland AMW, Niermeijer MF, Galjaard H, Reijniers E, Willems PJ, Halley DJJ: Assignment of a second locus for multiple exostosis to the pericentromeric region of chromosome 11. Hum Mol Genet 1994; 3: 167171.

29. Heutink P, van der Meij AGL, Sandkuyl LA, van Gils APG, Bardoel A, Breedveld GJ, van Vliet M, van Ommen GJB, Cornelisse CJ, Oostra B, Weber JL, Devilee P: A gene subject to genomic imprinting and responsible for hereditary paragangliomas map to chromosome $11 \mathrm{q} 23$ qter. Hum Mol Genet 1992; 1: 7-10.

30. Heutink P, Zguricas J, van Oosterhout L, Breedveld GJ, Testers L, Sandkuyl LA, Snijders PJLM, Weissenbach J, Lindhout D, Hovius SER, Oostra BA: The gene for triphalangeal thumb maps to the subtelomeric region of chromosome 7q. Nat Genet 1994; 6: 287-292. 


\section{H. Galjaard}

31. Hoogeveen AT, Willemsen R, Meijer N, de Rooy KE, Roos RAC, van Ommen GJB, Galjaard $\mathrm{H}$ : Characterization and localization of the Huntington disease gene product. Hum Mol Genet 1993; 2: 2069-2073.

32. The European Polycystic Kidney Disease Consortium: The polycystic kidney disease-1 gene encodes a $14 \mathrm{~kb}$ transcript and lies within a duplicated region on chromosome 16. Cell 1994; 77: 881-894.

33. Galjaard H: Challenges for the future; in Emery AEH, Rimoin DL (eds): Principles and Practice of Medical Genetics, ed 2. Edinburgh, Churchill Livingstone, 1991, pp. 2025-2035.

Correspondent: Prof. Dr. H. Galjaard, Department of Clinical Genetics, Erasmus University Rotterdam - P.O. Box 1738, 3000 DR Rotterdam, The Netherlands. 